\title{
Exchange of wife for social and food security: A famine refugee's strategy for survival (Gn 12:10-13:2)
}

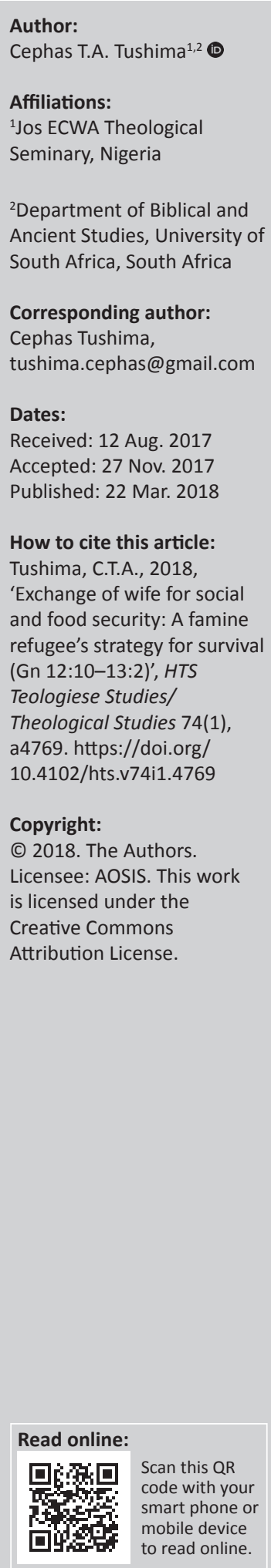

This essay studies Genesis 12:10-13:2 with a literary close reading approach that takes seriously the text's literary, historical and theological constituent elements. After a brief history of interpretation, it situates the narrative in its historical context, which is followed with a narrative critical reading of the text. The analysis of the text unveils the dissimulations of Abram, who manipulated his wife, Sarai, into thinking her beauty posed a threat to him, while his primary motive rested with the pursuit of economic gain in the face of the severe famine that had impoverished him in Canaan. Abram also succeeded in making Pharaoh believe that Sarai was his sister, on which account he exchanged her for material again. This analysis affords insight into the insecurity, anxiety, feelings of alterity of immigrant populations in their liminal conditions, the mistrust of immigrants by the state and host communities, and the ensuing power play (including sexual politics and/or commerce) with its concomitant perils. Through these, the passage speaks anew to contemporary communities of faith in view of the prevalent and ever-increasing migratory trends of the 21st century.

\section{Introduction}

Needy people in desperate situations are prone to adopting reckless strategies to address their problems. Situations of privation (whether because of poverty, war, famine or other calamitous causes) are the endemic instigators of actions of surprising dimensions. Think, for example, about a Cambodian mother who sold her daughter into sexual slavery in order to repay a \$200 shark loan that had ballooned into a $\$ 9000$ debt (Hume, Cohen \& Sorvino 2013); or poor parents in Brazilian favelas who push their young teen (or even pre-teen) daughters into the waiting hands of pimps on the streets in order to feed the family (Kuruvilla 2014). Genesis 12:10-13:2 presents a similar case of a desperate couple facing famine, and the husband doing the unimaginable of giving over his wife for material gain (cf. Westermann 1985:167).

Genesis 12 comes at the end of primeval history - the narrative of beginnings of everything in the human realm: the cosmos, humanity, the family, sin, murder, sexual perversion, industry and power tussle. Our study is concerned with social ethical problems, and we also see their root in primeval history. In primeval history's narratives, the first physical peril to human life (murder) occurs in Genesis 4, sexual perversion in Genesis 6 and power play (the war of the wills) in Genesis 11. The nature of narrative discourse rhetoric is different from that of overtly didactic literature. Narratives are known for 'showing' rather 'telling' their readers what to do (Long 1993:165-181), and this to a large degree rests in the actions or inactions of characters. Characters therefore constitute a major confluence of literary artistry and the ideological or ethical orientation of narrative discourse. Deriving ethical formulations from narratives therefore requires paying diligent attention to their characters.

\section{History of interpretation of Genesis $\mathbf{1 2}$}

Genesis 12:10-13:2 has long been recognised to have affinities with Genesis 20:1-18 and Genesis 26:1-13. The understanding of source critical scholars had been that the Genesis 12 story was the earlier of the stories, while the other two were latter interpretations and/or improvements upon it (Peleg 2006:197-208). In discussing these wife or sister passages in Genesis, for ease of reference, T.D. Alexander labels them, respectively, as A (Gn 12:10-13:1), B (Gn 20:1-18) and C (Gn 26:1-13). He points out that an array of scholars have always considered stories A and C as belonging to source J, while story B belongs to E (Alexander 1992:145-153; Skinner 1930:242-243, 315, 363; Speiser 1964:91; Von Rad 1973:226, 270). Rather than the traditional perceptions of stories B and C as latter interpretations or modification of A, John 
Van Seters sees them as literary compositions in their own right that have drawn inspiration from A (1975:167-169).

For some critics, the stories are not even from a common source. Hermann Gunkel (1997:168) argues that story A (which as he rightly marks out as Gen 12:9-13:4) consists of the 'core Abraham in Egypt Legend' (Gn 12:10-13:1), which comes from the main strand (namely, Ja), while the connecting seams (Gn 12:9 and 13:3,4) come from a related source $\left(\mathrm{J}^{\mathrm{b}}\right)$ and were inserted by a redactor $\left(\mathrm{R}^{\mathrm{J}}\right)$. Even its variant in Genesis 26 belongs to a different source strand, Jr (Gunkel 1997:293-298). At the end of his analysis of our primary text (story A), Gunkel conceives of its essence thus: 'The narrative glorifies the cleverness of the father, the beauty and self-sacrifice of the mother, and, especially the faithfulness of Yahweh' (1997:172). Gunkel's methodological approach is paralleled in several respects by his contemporaries, like Claus Westermann. However, Westermann differs significantly from Gunkel as to the sources of the three wife or sister stories in Genesis. While he firmly assigns story A to the Yahwist (J), he holds that B was composed out of reflections on $\mathrm{A}$, while in $\mathrm{C}$ :

Gen 26:1-11 is no more an independent and originally oral narrative than is $20: 1-18$. It is a literary imitation of $12: 10-20$ which at the same time takes up motifs from 20:1-18. (Westermann 1985:161-162, 318-320, 424)

The problems associated with these kinds of analyses have been well articulated, and one forbears rehearsing them here. As an illustration, in his scathing reproof of form criticism (as an insider), James Muilenberg (1969) writes:

To state our criticism in another way, form criticism by its very nature is bound to generalize because it is concerned with what is common to all the representatives of a genre, and therefore applies an external measure to the individual pericopes. It does not focus sufficient attention upon what is unique and unrepeatable, upon the particularity of the formulation. Moreover, the form and the content are inextricably related. They form an integral whole. The two are one. Exclusive attention to the Gattung may obscure the thought and intention of the writer or speaker. The passage must be read and heard precisely as it is spoken. It is the creative synthesis of the particular formulation of the pericope with the content that makes it the distinctive composition that it is. (p. 5)

The textual prehistory is certainly important; however, historical studies of the last century made the reading of the biblical text an elitist endeavour, a negation of the essence of the Reformation. Besides, after the text has been balkanised into various sources or layers of redactions, it is uncertain as to what remains as the Bible of the communities of faith. Whatever the pre-history of a text, its final canonical shaping severs its component parts from their moorings and gives them a new form, context and meaning. This is what Muilenberg refers to as 'the creative synthesis' that makes the text a distinctive composition, and it should be taken seriously.

The 1970s ushered in a new era of the new literary critical interpretive approaches, which Bill T. Arnold refers to as the phase of nascent literary criticism. During this time, 'rhetorical or aesthetic criticism attempted to overcome the atomizing excesses of source- and form-criticism' (Arnold 2009:13; cf. Reis 1992:306-315). With this orientation, exegetes moved away from giving excessive attention to matters that are extraneous to the text and began to give greater consideration to the structural frameworks of the stories, their developments (plots), characters, literary features and hermeneutical significance.

A good example of the study of this passage with the literary critical approach is an essay by Richard L. Pratt (1983:156-167), written over 30 years ago, in which he states that Christians conceive of the Bible as canon, history and a source for nourishment. These three concepts, he says, correspond, respectively, to his three metaphors of pictures, windows and mirrors, and the corresponding methodological approaches for each of them are literary analysis, historical analysis and thematic analysis. His concern is that each of these perspectives should be given good attention in exegesis for greater insights and creative understandings of Old Testament (OT) narratives (Pratt 1983:159). In his survey of Protestant interpretations of Genesis 12:10-20, Pratt concludes:

[I]n each case the primary, if not exclusive, concern has been with historical and thematic dimensions of the story. These reflections are legitimate and important, but they ignore the text as a picture. Consequently, they leave untouched much that the story has to offer. A literary analysis of the pericope opens the way for understanding the story in ways which break with traditional approaches. (Pratt 1983:159; cf. Keil \& Delitzsch 1949:1.197; Skinner 1930:24; Von Rad 1973:168)

Pratt then goes on to make a lucid literary analysis of the passage, paying attention to the rhetorical import of structuring and other literary devices, as well as the role of each character in the narrative.

More recent studies have focused on ideological readings of the passage with concerns for the injustices of patriarchy and androcentrism in the biblical text, its God, its authors and its modern male interpreters (Bergant 2013; Rashkow 1993; Trible 1978). There has been a resurgence of historicism, perhaps of a different kind, particularly in the new millennium. While those who are inclined to historical studies are becoming more willing to pay attention to the rhetorical sophistication of the text, those who pursue literary critical analysis are seeking historical grounding for their literary critical works. This is what Arnold calls the maturation of the literary critical approaches (Arnold 2009:13-14). Writing his commentary in this new stream, Arnold begins first with the historical grounding of his work before moving into a more literary analysis of the text. He accepts $J$ as the source of Genesis 12 and states that it was composed terminus ad quem in the 8th century BCE by the Yahwist, a historian of the southern kingdom of Judah. He is, however, dubious of E's existence as a separate source, and points out that several scholars have understood it to be a supplement to J (Arnold 2009:15; cf. Friedman 1998:3-56). 
The call for the incorporation of every facet of the text in its study is not new, but it should not be ignored. Pratt's conception of the text as picture (canon), window (history) and mirror (spiritual food) corresponds to what Cephas T.A. Tushima's three essential constituent elements of the biblical text, namely literary artistry, history and theology, each of which is implicated in the others such that attempts to separate or isolate them only tend to obfuscate the meaning of the text rather than elucidate it (2011:82-83). To ensure a holistic stance (incorporating the literary, historical and theological elements) in textual analysis, Tushima (2011:83) advocates the adoption of a historary (a term of his own coinage) methodological approach. This is the approach that is adopted in this study.

\section{The historical and literary context of Genesis 12:10-13:2}

Context is critical in any hermeneutical endeavour, and ours is no exception. I have explored the context of this passage with respect to adultery in the ancient times, the compositional or redactional historical context and the literary context of the text. There was an unmistakable moral consensus amongst the ancients regarding adultery. Many civilisations of the ancient world have left written laws prohibiting adultery, for example, the Decalogue and other such passages of the Torah. Jeffrey Howard Tigay defines adultery as 'voluntary sexual intercourse between a married woman, or one engaged by payment of the bride price, and a man other than her husband', and he expatiates specifically from the perspective of the ancient:

The extramarital intercourse of a married man is not per se a crime in biblical or later Jewish law. This distinction stems from the economic aspect of Israelite marriage: the wife was the husband's possession (of a special sort), and adultery constituted a violation of the husband's exclusive right to her; the wife, as the husband's possession, had no such right to him. (Tigay 2008)

It is not surprising that laws concerning adultery are often stated in proximity to laws regarding property. In the Decalogue, for example, the 7th commandment forbidding adultery is next to the prohibition of stealing. Similarly, the 10th commandment lists the wife amongst the neighbour's property that must not be coveted (Ex 20:14-17). The sexual violation of a husband's sole proprietary right to his wife was a capital offense (Lv 20:10; Dt 22:22).

The laws of other peoples of the ancient Near East, some of which predates the Mosaic laws (and are even closer to Abraham's time) bear close resemblances to Mosaic prescription and shed light on our text. The stele bearing Hammurabi's law code states that it was published in the second year of his reign: Hammurabi reigned from 1728 to 1686 (circa). In this code, law \#129, regarding adultery, states:

If the wife of a seignior has been caught while lying with another man, they shall bind them and throw them in the water. If the husband [Lit., 'owner or master'] of the woman wishes to spare his wife, then the king in turn may spare his subject. (Pritchard 1969: 171)
The husband is thus seen in this law as an owner (similar to a property owner) or a master, like in a slave-master relationship, which is still a proprietary relationship. The offense is a capital offense, but as it is primarily against the husband, he has the prerogative of deciding whether his wife dies or lives.

Middle Assyrian Empire (1392-1056 BC) laws have several provisions regarding different sexual infractions of a married woman. Law \#15 states:

If a seignior has caught a(nother) seignior with his wife, when they have prosecuted him (and) convicted him, they shall put both of them to death, with no liability attaching to him. If, upon catching (him), he has brought him either into the presence of the king or into the presence of the judges, when they have prosecuted him (and) convicted him, if the woman's husband puts his wife to death, he shall also put the seignior to death, but if he cuts off his wife's nose, he shall turn the seignior into a eunuch and they shall mutilate his whole face. However, if he lets his wife go free, they shall let the seignior go free. (Pritchard 1969: 181; for similar laws amongst the Hittites, see Pritchard 1969: 196; for the Middle-Assyrian Empire, see Kertai 20082009:25-51)

Thus, the offence is grave and has implication for public morality, but as the wife belonged to the husband, he will have the final say in the matter. This was the legal context of the ancient Near East regarding husband-wife relationships and issues of sexual perversion, and this is the environment in which the patriarchs lived. The absolute control a husband had over his wife in this era therefore provides a basis for understanding (though not excusing) the way Abram behaved in our story.

Another important aspect of context has to do with compositional history: the authors or redactors and their first recipients. The Torah (Genesis inclusive) has a complex compositional history. While conservative scholarship has held to Mosaic authorship, critical scholarship has proposed various periods of redaction, ranging from the united monarchy, to the divided kingdom, and on to the late preexilic, exilic and post-exilic periods. One thing is certain: while the core of the book may have had a much earlier history, it contains indicators of later redactions, a few examples of which will suffice. Firstly, Abram is said to have pursued the captors of Lot as far as the city of Dan (Gn 14:14), but the DtrH indicates that the city was previously called Laish, and its capture and renaming took place late in the settlement period (Jdg 18:29). Secondly, Genesis 36:31, in giving the generations of Edom states, 'These are the kings who reigned in the land of Edom, before any king reigned over the Israelites' (ESV). To speak about a king reigning in Israel presupposes that the monarchy was already in place. Certainly, this was not in the time of Moses. Thirdly, in Abraham's encounter and covenant with Abimelech of Gerar, the narrator refers to the land of Abimelech as the land of the Philistines. The first wave of Philistine migration (they were called the Sea Peoples) was rebuffed in Egypt by Rameses II (1182-1151 BCE). The Philistines succeeded in wresting the 
coastal areas of Palestine from Egypt in the second half of the 12th century and made it their home (Finkelstein 1995:213-239). This clearly demonstrates that there were no Philistines in Palestine when Abraham was there. Thus, the reference to them is anachronistic.

The above only goes to confirm what James A. Sanders conceives as the stability and adaptability of the canon (Sanders 1976:402-471; cf. Childs 1968:284-298; 1976; 1979:56). This has to do with the Israelite community's efforts to discover its self-identity vis-à-vis its sacred traditions. In the process, the community continuously re-interprets its authoritative traditions to address emergent challenges in its ever-new existential circumstances. In expatiating on the fixity and fluidity of the canon, Childs notes, 'It is stable in the sense of having an established structure and content; it is adaptable in addressing the community in each new generation' (1979:57). This goes to show how the biblical text remained alive amongst its earliest readers, re-contextualising itself in each new era. Thus, its various contexts remain hermeneutically relevant to contemporary readers, endowing it with the ability to re-contextualise and speak to its readers in diverse times and locations.

Construed in this way, Genesis 12 remained relevant to its audience whether in the time of Moses, during the exodus, or in the post-exilic era. Either way, the challenges of migration, subservience under powerful overloads and moral dilemmas would have still been issues with which either community would have had to deal. The understanding that the Genesis 12:10-20 story foreshadows the exodus is common knowledge amongst biblical commentators (see Arnold 2009:13; Holmgren 2010:366-377). Pratt acutely demonstrates how it should have been used to minister both to the exodus and the post-exilic communities. Regarding the former, Pratt (1983) notes:

When consideration is given to the experiences of Moses recorded in Exodus and their correspondence to Gen 12:10-20, it becomes apparent that Moses expressed these events in Abram's life in such a way as to make them parallel the deliverance of Israel from Egypt. Abram sojourned in Egypt because of a famine in Canaan; a famine drove Jacob and his sons into Egypt for food. Deception was characteristic of Abram; Joseph's brothers are known for their lies. While in Egypt, Abram prospered but his hope for progeny was fading because Pharaoh had taken Sarai; Israel increased in number in Egypt but slavery and the slaughter of male infants presented a threat to posterity. (pp. 165-166)

On this trajectory, several parallels would have been drawn to help the Israelites see that the search for food in the face of famine resulted in the captivity of Sarai, just as the same had happened to the sons of Jacob. Yet, as Yahweh had brought Abram and his family back to Canaan, God would lead Israel into the Promised Land.

Placing the story in the late exilic or post-exilic period would bring about effects similar to those in the Mosaic era. On this note, Pratt (1983) argues:
It was Abram's fear of foreign powers which led him to distrust Yahweh's power to protect him. His infidelity ended in captivity in another land; it was Judah's fear of foreign authorities which eventually led to exile in Babylon. Yahweh intervened on the behalf of Abram; he did so for Judah as well. (p. 166)

Indeed, the prophets had already interpreted the return from exile as a second exodus. Thus, the actual time of composition of the story is immaterial; the important point is that it continuously spoke to successive generations of the biblical communities of faith.

Finally, the literary context of the text is equally important. It occurs early in the Abrahamic cycle of narratives (Gn 12-26), which follows on the heels of primeval history. This narrative is part of the beginning of the patriarchal narratives that run through the rest of the book of Genesis. One of the dominant motifs amongst them is migration: people were constantly moving from one place to another, and developing strategies for overcoming the challenges of alterity and surviving in those places to which they went (Abraham, Hagar and Ishmael, Isaac, Jacob, Esau, Joseph and Jacob's sons and their families).

This text has the same capacity to speak to communities of faith today. Moral dilemmas are present today as they were in ancient times. Migration will continue to be a recurring aspect of contemporary life, as in the past. The same anxieties and apprehensions concomitant with the liminality of recent immigrants are true today as they were in olden days. Similarly, the phobia that state authorities have of immigrants and the temptation for immigrants to adopt subversive behaviour to outwit those authorities are still engrained in modern immigrant psyche as much as ever, hence the potency of this text to speak anew in our times.

\section{Literary analysis of Genesis 12:10-13:2}

This passage can be broadly divided into three main sections, namely, Abram on the way to Egypt (12:10-13), Abram in Egypt (12:14-19) and Abram on his way from Egypt to the Negev (12:20-13:2). Indeed, as Gunkel (1997:168-170) shows, the boundaries of this passage could be expanded to begin from Genesis 12:8 and continue to 13:4, but we will discuss this fully later. However, the entire pericope forms such a perfect chiasm that it transcends being divided otherwise, and we will proceed to discuss it based on its chiastic structure.

\section{Chiastic structure of Genesis 12:8-13:4}

A Opening bracket of the story: Abram builds an altar, worships Yahweh and journeys from Bethel to the Negev (Gn 12:8-9).

B Abram faces famine in Canaan and journeys from the Negev to Egypt (Gn 12:10)

C Abram's speech to Sarai before his entry into Egypt (12:11-13) 
D Abram exchanges Sarai for prosperity in Egypt (12:14-16)

D' Pharaoh marries Sarai but is afflicted with his house (12:17)

$C^{\prime}$ Pharaoh's speech to Abram before his departure from Egypt $(12: 18-19)$

B' Abram receives abundance from Egypt and journeys from Egypt to the Negev (Gn 12:20-13:2)

A' Closing bracket of the story: Abram journeys from the Negev to Bethel, visits his altar and worships Yahweh (Gn 13:3-4)

In this chiasm, everything builds up in concentric circles to a climax at the centre (D and $\left.\mathrm{D}^{\prime}\right)$. The outer rings of the chiastic structure consist of the starting and terminal points of Abram's Egyptian escapade ( $\mathrm{A}$ and $\left.\mathrm{A}^{\prime}\right)$. Both $\mathrm{A}$ and $\mathrm{A}^{\prime}$ fall somewhat outside the main pericope, and they seem to have been employed parenthetically to differentiate this unit from the preceding journey from Haran to Canaan (Gn 12:1-7) and the subsequent separation of Abram and Lot (Gn 13:5-18). By the skilful bracketing of this pericope, the narrator highlights that it was a misadventure on the part of Abram. It is more like a detour, and ineluctably Abram had to resume his covenantal journey at Bethel, from whence he had veered off to Egypt (Gn 13:3-4).

Several subtle motifs and lexemes intricately connect these two bracketing seams of the text. Table 1 vividly portrays how Abram retraced his steps, except that he did not go as far as Shechem. The narrator carefully chooses his words to reflect these movements. For example, in $\mathrm{Z}$ and $\mathrm{Z}^{\prime}$, there is a deliberate use of the word roots הסע ה הלך in ways that are difficult to translate accurately. The essence of what they say is well captured by the New Living Translation (NLT), as in both cases it renders the statement to the effect that he 'continued traveling by stages toward' either the Negev (12:9) or Bethel (13:3). Abram retraced his steps not only in the nature of the journey but also in terms of destination. When he had arrived at Bethel from Shechem, he set up his camp east of Bethel but west of $\mathrm{Ai}(\mathrm{W})$; similarly, on his return journey from the Negev $\left(W^{\prime}\right)$, he returned to the same place. This point is stressed using the noun phrase בתחלה [in the beginning], which here functions adverbially.

When he arrived in Bethel at the first instance, he built an altar there $(X)$. Now as he finds his way back home $\left(X^{\prime}\right)$, he returns to where he had built his altar on his first arrival. This is a kind of covenant renewal - the journey to Egypt being a deviation from the covenantal path. The altar is the place of worship. When Abram built the altar at first, he worshipped Yahweh (Y); now as he returns $\left(\mathrm{Y}^{\prime}\right)$, his worship of Yahweh, which had been suspended all the time that he had been away in Egypt, is now resumed. The clause ויקרא בשם יהוה literally translates as 'and he called on the name of the LORD'. However, I have rendered it as 'worshipped the LORD' because the verb קרא when used with respect to God has the sense of deferentially appealing to a deity out of reverence and doing so in a sense of dependence (cf. $1 \mathrm{Kgs}$ 8:52; 18:24; 1 Chr 4:10; Ps 86:5; see Holladay 2000, 323).

B and $\mathrm{B}^{\prime}$ in Table 2 reveal the state in which Abram was before he set out on his journeys in the first instance from the Negev to Egypt (B), and in the second instance from Egypt to the Negev ( $\left.B^{\prime}\right)$. The announcement of Abram's journey towards Egypt (B, v. 10) is stated in two sentences, in both of which a reference is made to the famine; and the twofold mention of famine constitutes an inclusio around Abram's departure for Egypt. The structure of the sentence is set out as Table 2.

Table 2 brings to light several salient issues. B consists of two main clauses (F and $G$ ) and two subordinate clauses: the first is an infinitival purpose clause $(\mathrm{H})$ providing the reason for Abram's trip to Egypt, namely to sojourn there. The second is a prepositional explanatory subordinate clause (I) providing the reason for Abram's proposed sojourn to Egypt: the famine was severe in Canaan. The unit begins with the announcement of the famine and ends with a statement about the severity of the famine. This accounts for Abram's movement to Egypt, as Egypt, unlike other regions of the ancient Near East (ANE), had food security because of the Nile. Thus, in calamitous times, many peoples in the ANE would flock to Egypt. In a similar vein, Walton, Matthews and Chavalas write, 'Egypt served as both a market as well as a source of food and temporary employment for many groups driven by war or famine from the rest of the Near East' (2000: 45). B', on the other hand, consists of three main clauses on the story line $\left(F^{\prime}, F^{\prime \prime}, G^{\prime}\right.$ or $\left.H^{\prime}\right)$, while $I^{\prime}$ is a resumptive epexegetical pronominal phrase amplifying the subject of the previous clause - specifying the people and possessions that Abram took with him on his return journey to the Negev. Additionally, I" further expands the phrase וכל-אשר-לו [all that belonged to him], that as Abram was departing Egypt, unlike the poverty

TABLE 1: Comparison of bracketing seams of Abram's journey to and from Egypt Narrative (outer ring of the chiasm: $A$ and $A^{\prime}$ ). ${ }^{1}$

\begin{tabular}{|c|c|c|c|}
\hline $\begin{array}{l}\text { Chiastic unit } \\
\text { identifier }\end{array}$ & Genesis 12:8-9 - A & Genesis 13:3-4 Return Journey - $A^{\prime}$ & $\begin{array}{l}\text { Chiastic unit identifier } \\
\text { (the obverse side) }\end{array}$ \\
\hline V & 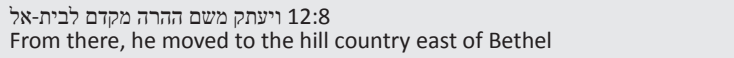 & $\begin{array}{l}\text { 13:4 וילך למסעיו מנגב ועד-בית-אל he continued traveling from the Negev to Bethel } \\
\text { Then, he }\end{array}$ & $Z^{\prime}$ \\
\hline w & 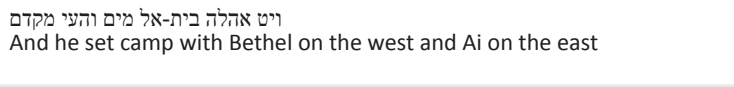 & $\begin{array}{l}\text { עד-המקום אשר-היה שם אהלה בתחלה בין בית-אל ובין העי } \text { שית the where his camp was in the beginning } \\
\text { towards the place whereen Bethel and Ai }\end{array}$ & $W^{\prime}$ \\
\hline$x$ & $\begin{array}{l}\text { ויבן-שם מזבח ליהוה } \\
\text { And he built an altar there to the LORD }\end{array}$ & $\begin{array}{l}4 \\
4 \text { אל-מקום המזבח אשר-עשה שם בראשנה } \text { של the place of the altar which he had made there at first } \\
\text { to the }\end{array}$ & $\mathrm{X}^{\prime}$ \\
\hline Y & $\begin{array}{l}\text { ויקרא בשם יהוה } \\
\text { And he worshipped the LORD }\end{array}$ & $\begin{array}{l}\text { ויקרא שם אברם בשם יהוה } \\
\text { And there Abram worshipped the LORD }\end{array}$ & $Y^{\prime}$ \\
\hline Z & $\begin{array}{l}9 \\
\text { ויסע אברם הלוך ונסוע הנגבה } \\
\text { Abram set out (from Bethel) and continued traveling towards the Negev }\end{array}$ & & \\
\hline
\end{tabular}

${ }^{1}$ Hebrew text source for this article: https://www.ccel.org/a/anonymous/hebrewot/Genesis.html 
TABLE 2: Comparison of Abram's state before journey to and departure from Egypt (second ring of the chiasm: B and B').

\begin{tabular}{|c|c|c|c|}
\hline Chiastic unit identifier & Genesis 12:10 - B & Genesis 12:20-13:2 - B' & Chiastic unit identifier (the obverse side) \\
\hline \multirow[t]{2}{*}{$\mathrm{F}$} & $\begin{array}{l}\text { ויהי רעב בארץ famine in the land } \\
\text { Now there was faming }\end{array}$ & $\begin{array}{l}\text { 12:20 ויצו עליו פרעה אנשים } \\
\text { So Pharaoh commanded his servants concerning him; }\end{array}$ & $\mathrm{F}^{\prime}$ \\
\hline & & $\begin{array}{l}\text { וישלחו אתו ואת-אשתו ואת-כל-אשר-לו } \\
\text { and they drove him away with his wife and all that belonged to him. }\end{array}$ & $F^{\prime \prime}$ \\
\hline G & $\begin{array}{l}\text { וירד אברם מצרימה } \\
\text { So Abram went down to Egypt }\end{array}$ & $\begin{array}{l}\text { 2:31 ויעל אברם ממצרים up from Egypt, } \\
\text { Then Abram went up }\end{array}$ & $\mathrm{G}^{\prime}$ or $\mathrm{H}^{\prime}$ \\
\hline $\mathrm{H}$ & $\begin{array}{l}\text { לגור שם } \\
\text { To sojourn there }\end{array}$ & & \\
\hline \multirow[t]{2}{*}{ I } & $\begin{array}{l}\text { כי-כבד הרעב בארץ } \\
\text { For the famine was severe in the land. }\end{array}$ & $\begin{array}{l}\text { הוא ואשתו וכל-אשר-לו ולוט עמו הנגבה } \\
\text { he and his wife and all that belonged to him and Lot with him, } \\
\text { towards the Negev. }\end{array}$ & $\mathrm{I}^{\prime}$ \\
\hline & & $\begin{array}{l}\text { ואברם כבד מאד במקנה בכסף ובזהב } \\
\text { And Abram was heavily endowed with cattle, silver and gold. }\end{array}$ & $\mathrm{I}^{\prime \prime}$ \\
\hline
\end{tabular}

TABLE 3: Comparison of the monologues of Abram and Pharaoh (third ring of the chiasm: $C$ and $C^{\prime}$ ).

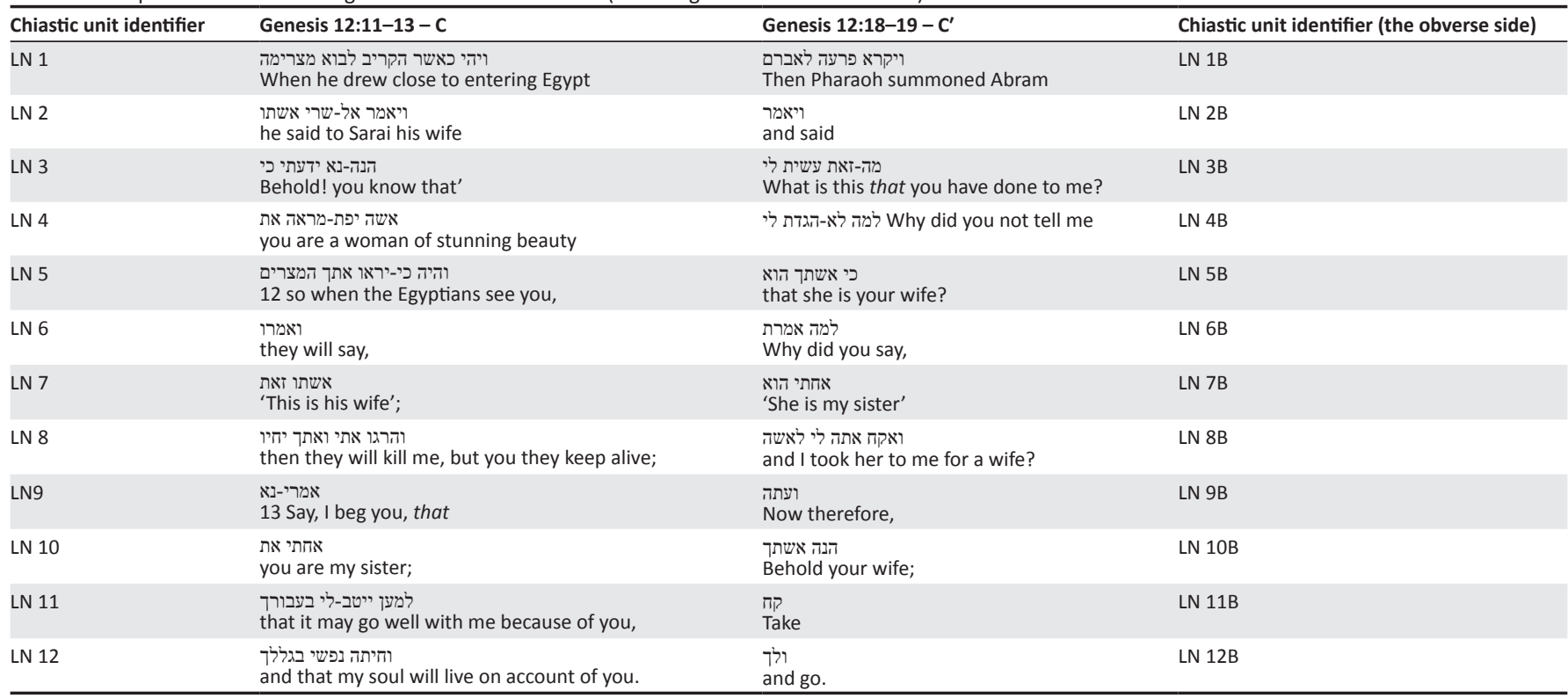

that brought him there, he had already been heavily endowed by Pharaoh with cattle, silver and gold (note that waw-copular nominal clauses tend to describe states that are contemporaneous with the principal actions of the immediately preceding clauses, cf. Kautzsch 1910, §141.e. On Genesis 13:2, this position is contra Joüon-Muraoka (2006:566), who views the verse as linked to v. 3 rather v. 1). While famine (F) had impelled Abram into Egypt, Pharaoh's command $\left(\mathrm{F}^{\prime}\right)$ and the execution of that order $\left(\mathrm{F}^{\prime \prime}\right)$ hounded Abram out of Egypt. In the former case, he went willingly (even though motivated by environmental factors); in the latter case, he was forced out.

In Table 2, F and I show Abram's material state; he left the Negev in severe famine. Though not explicitly stated, this implies that he was in a state of penury; no possessions are attached to him at this time. This contrasts sharply with both his initial movement from Haran to Canaan (Gn 12:5) and his subsequent departure from Egypt (Gn 12:20-13:2). Conversely, F" and I' with I" state Abram's changed state; he became a wealthy man. This fact is stated more plainly in Genesis 13:2, but it is the core of the chiasm that sheds more light on how Abram became so wealthy. Finally, we see Abram's movement: in G, Abram goes down to Egypt, while in $G^{\prime}$ and $H^{\prime}$, he goes up to the Negev. There is perfect reciprocity of action, such that every action generates counteraction.

The next concentric circle in the chiastic structure is shown in Table 3 and consists of $C$ and $C^{\prime}$, which is made up primarily of monologues (for contra views, see Jeansonne 1990:17; Steinberg 1993:53; van Dijk-Hem 1993:227; Westermann 1985:163), that of Abram to Sarai (C) and that of Pharaoh to Abram $\left(C^{\prime}\right)$. Both speeches are carefully crafted in highly elevated prose that approximates poetry. Although rhyming is not common in Hebrew poetry, the clause-by-clause division of these speeches has produced amazing rhymes in each of them. In the C-section, the $ת$ terminal sound is found after every three lines (LN 4, LN 7 and LN 10), there is a semantic rhyme (Egypt ending a clause) in LN 1 and LN 5, the rhyme of 7 occurs in LN 6 and LN 8 and 7 terminal sound is in the final clauses of LN 11 and LN 12. In the $C^{\prime}$ side of the table, the terminal sound occurs in LN 3B, LN 4B, LN 8B and LN 9B; הוא terminal sound is found in LN 5B and LN 7B and again, the 7 terminal sound is in the final clauses of LN 10B, LN 11B and LN 12B.

In Table 3, C contains Abram's monologue to Sarai, in which he highlighted her beauty and the danger it held for him. Conversely, C' comprises Pharaoh's reproof of Abram for the 
latter's dissimulations (for different views, see Calvin 1948:521, 529; Reis 1992:309) and the harm it has caused the former. While the former monologue addresses probability, the latter reflects upon actuality. The parallels that exist between the two speeches are stunning, and are the work of skilful literary penmanship. These are further highlighted herein.

In Table 3, LN 1 and LN 1B consist of circumstantial clauses (although, grammatically, this is truer of LN 1 than of LN 1B, semantically both are performing the same function) that show when or what precedes the speech proper. LN 2 and LN 2B contain quotation formulae; and both LN 3 and LN 3B call the addressee to reflect: the one on her beauty and the other on his deceit. While LN 6 is a quotation formula suggesting what the Egyptians would say upon seeing Sarai, LN 6B is quotation formula recalling what Abram had said to the Egyptians: While Abram anticipated that the Egyptians would make a correct assessment of his relationship with Sarai, the Egyptian (Pharaoh) recalls the lie Abram had told about his relationship with her. Abram's intention of commodifying Sarai in Egypt is manifest even by the pronoun he employed in his putative speech of the Egyptians, אשתו זאת [This is his wife]. The demonstrative pronoun זאת is feminine quite alright, but it is used more commonly of things, and especially in a non-pointing encounter (as in his anticipatory speech), it is uncalled for (with regard to humans, BDB 1907:260, lists this verse amongst those where זאת is used contemptuously). Surprisingly, it is Pharaoh instead who humanises Sarai in his quotation of what Abram had said, אחתי הוא ('She is my sister'). Where Abram said, 'This [commodity] is my sister', Pharaoh heard, 'She [person] is my sister'. In LN 8, Abram suggests that he will be killed because of Sarai, but in LN 8B, it is Sarai who is 'killed' (violated) because of Abram.

Both LN 9 and LN 9B signal the concluding parts of the speeches. On the one hand, LN 10 is a perversion of the truth expressed in LN 7, and on the other hand, LN 10B is a reversal of the travesty of LN 7B. In LN 11, we come to the main aim of Abram's falsehood: material gain. Escaping from a desperate situation of famine, want and need, he found the beauty of Sarai a ready commodity. While he presented before Sarai that her beauty posed real danger to his life, the first benefit of the lie he concocted is not life but material gain. In LN 11B, Abram had a doubling of his 'taking'. While he first took material possession (as his speech anticipated), now after the fact, he is again offered his wife back. LN 12 has the supposed secondary goal of Abram's life. This life he receives in Pharaoh's speech in the form of freedom ('Go'), for Pharaoh now had reason to have killed him, but he let him go. Indeed, commenting on this issue, Wal (2008) observes:

It is no small thing that Pharaoh appears to have more faith in God, more respect for God, and more Godlike qualities than Abram does. With grace, reminiscent of God, Pharaoh gives Abram what he has not earned: freedom with all his gifts intact. (pp. 79-82)

In the speeches of both Abram and Pharaoh, the 'Thou- $\mathrm{I}^{\prime}$ factor is skewed heavily with the accents falling on 'you'. Taking all the pronominal forms into account (i.e. both the independent and the embedded, whether in the nominative, genitive or accusative case), 'you' occurs at least seven times in Abram's speech and six times in Pharaoh's speech. Conversely, 'me' occurs four times in Abram's speech and three times in Pharaoh's speech. What this clearly shows is that in either case, the speaker tells the addressee, 'You are my problem'. While this is true in Pharaoh's case, in Abram's case, he employed manipulative intimidation to coerce Sarai into playing along in his scheme: note that Sarai's complicity is not explicit; unlike in Genesis 20, where Abimelech accuses both Abram and Sarai of lying to him, in this case, Pharaoh quotes only Abram's speech.

In Table 4, LN I to LN V record the entry of Abram and his entourage into Egypt and the excited response of the Egyptians upon seeing Sarai. This culminated in them recommending her to be added to the Pharaoh's harem. The text then says laconically that she was taken to Pharaoh's house (Gn 12:15c). A casual reading may suggest that she was seized and carried off to Pharaoh's house. However, in his reproof of Abram, Pharaoh queried Abram as to why he had told him that Sarai was his sister (v. 18). This presupposes discussion and marriage negotiation, hence Pharaoh's angst over the whole affair. Van Seters (1975:77), similarly, holds to

TABLE 4: Showing the benefits of Abram and the Peril of Pharaoh on account of Sarai (inner [core] ring of the chiasm: $D$ and $D^{\prime}$ ).

\begin{tabular}{|c|c|c|c|}
\hline Chiastic unit identifier & Genesis 12:14-16 - D & Genesis 12:17 - $\mathrm{D}^{\prime}$ & Chiastic unit identifier (the obverse side) \\
\hline LN I & $\begin{array}{l}\text { 12:14 ויהי כבוא אברם מצרימה Now when Abram entered Egypt, } \\
14 \text { Now }\end{array}$ & & LN IB \\
\hline LN II & $\begin{array}{l}\text { ויראו המצרים את-האשה } \\
\text { the Egyptians saw the woman }\end{array}$ & & LN IIB \\
\hline LN III & $\begin{array}{l}\text { כי-יפה הוא מאד } \\
\text { that she was exceedingly beautiful. }\end{array}$ & & LN III \\
\hline LN IV & $\begin{array}{l}15 \text { When the principal officers of Pharaoh saw her, } \\
15 \text { ויראו ארי פרה }\end{array}$ & & LN IVB \\
\hline $\operatorname{Ln} \mathrm{V}$ & $\begin{array}{l}\text { ויהללו אתה אל-פרעה } \\
\text { they praised her to Pharaoh; }\end{array}$ & & LN VB \\
\hline LN VI & 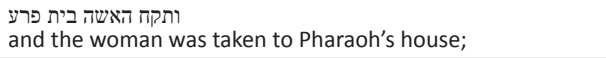 & & LN VIB \\
\hline LN VII & $\begin{array}{l}\text { ולאברם היטיב בעבורה } 16 \text { and he (Pharaoh) dealt so favourably well with Abram } \\
\text { because of her, }\end{array}$ & \multirow{2}{*}{ 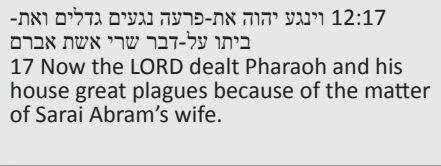 } & \multirow[t]{2}{*}{ LN VII or VIIIB } \\
\hline LN VIII & $\begin{array}{l}\text { ויהי-לו צאן-ובקר וחמרים ועבדים ושפחת ואתנת וגמלים (Abram) became the owner of flocks, cattle, male } \\
\text { that he (Abram } \\
\text { donkeys, man-servants, maid-servants and female donkeys. }\end{array}$ & & \\
\hline
\end{tabular}


the possibility that Abram could have legitimately given Sarai out in marriage as her brother. This is comparable to Laban, as brother, being the lead person negotiating Rebekah's marriage (Gn 24).

Up to the end of Genesis 12:15c (LN VI in Table 4), it was other people (Pharaoh's servants, presumably) who were acting towards Sarai on Pharaoh's behalf, for Abram's benefit because of Sarai - as Abram had desired (Gn 12:16; cf. 12:13b). This corresponds to Genesis 12:17 (LN VII or VIIIB in Table 4): Yahweh here acts towards Pharaoh and his house on Sarai's behalf to Abram's benefit. The former actions of Pharaoh's servants brought restriction and deprivation to Sarai, but pleasure and prestige to Pharaoh. The latter action of Yahweh brought peril and pain to Pharaoh, but restoration and freedom to Sarai. Abram the fearful (outwardly powerless) famine refugee, through shrewd scheming, subverts the power of Pharaoh, exploits the might of Yahweh and commodifies the sexuality of his wife to become the chief beneficiary in all that transpired. Some may think this statement too strong. However, Yahweh, in covenant relationship, had made an unconditional commitment to protect Abram (Gn 12:3). Therefore, as he deliberately deceived both Sarai (by making her believe her beauty posed a risk to his life, while he was using that as decoy to gain wealth) and Pharaoh (by making him believe Sarai was his sister and thereby collecting bride wealth from him), he was endangering their lives, because he would come out unscathed because of assured protection from Yahweh.

\section{The theological or ethical implication of the study}

Genesis 12:1 (with Abram's call) is the point at which the plot of the larger Abraham narrative cycle begins, but the foreground of our pericope is Genesis 12:8-9, which highlights Abram's initial settlement in Bethel and his piety. The immediate setting of this story is Genesis 12:10, which recounts the famine in the land. This is the Promised Land, and the greatest promise that Yahweh gave to Abram was his abiding blessing (Gn 12:2-3). In his moment of crisis, Abram did not resort to Yahweh but found his way to Egypt. The divine response to Abram's action that becomes immediately evident is absence and silence. In Abram's first journey (from Haran to Canaan), he experienced divine presence and assurance (communication) both at the initial and terminal points of the journey (Gn 12:1-7), and implicitly in between as well. At the beginning of this new journey until his eventual return, Abram experiences neither theophany nor divine communication, indicative of divine disapproval. This is a call to walk with God all the time, as Yahweh would later explicitly require of Abram (cf. Gn 17:1).

Next, in the narrative plot is the point of rising tension (Gn 12:11-13). Abram and his family are at the cusp of entering Egypt, where he intimidatingly manipulates Sarai to the effect that her stunning beauty was a threat to his life and to save his life, she must feign she is his sister (for a contra view, see Clines 1990:69-72). The entire monologue was contrived to simulate fear generated by the feeling of marginality and powerlessness arising from a sense of alterity and displacement. The theme of desire (sybaritic sexual desire) is hinted at by Abram's reference to how Sarai is beautiful to behold (מראה), and how the Egyptians would react when they see (כי-יראו אתך) her; note the use of the verbal root for 'to see' (ראה) in both statements.

Sarai remained silent, and the text remains ambiguous as to whether she was persuaded or not, but obviously, she did not have much choice within the context of her culture. In the family, all power resides with the male head in patriarchal societies. The divine response here was silence, mirroring the powerlessness of Sarai. The implication of this is that Yahweh sides with the oppressed: as his later action overtly demonstrates what is only implied here, so must his people also learn to walk with the oppressed in the search for justice.

The climax of the story comes in Genesis 12:14-17, with the characteristic multiplicity of characters doing diverse things. As anticipated, all of Egypt went agog upon seeing the beauty of Sarai. She became objectified as a sex object, and yet the balance of power tilted indubitably in favour of the most powerful individual in the land, Pharaoh. Just as in Abram's speech, the focus on the desirability of Sarai for sexual passion is highlighted by a double use of the root for see (ראה, cf. vv. 14-15). Powerless, Sarai acquiesces, and Abram passes her on to Pharaoh. Thus, Sarai enters Pharaoh's harem. In return, as Abram had hoped (that it will go well with him on account of Sarai), Pharaoh unleashes royal beneficence on Abram so that overnight, he rises from indigence (because of the famine in Canaan) to opulence (v. 16). Yahweh still remained silent and absent, indicating disapproval of all that has transpired, and in a sense, he is also grieving with Sarai.

Yet, just as Pharaoh's servants acted towards Sarai for the benefit of Pharaoh (v. 15), Yahweh also acts towards Pharaoh for the benefit of Sarai by inflicting Pharaoh (and his house) with a great plague, putting Pharaoh and his house in peril (v. 17). The divine response indicates divine disapproval of overreaching and, by implication, greed. Though not stated in the text, in tandem with ANE culture, Pharaoh would have had many wives. There was no need for him to seek to marry a woman who was already over 65 years old. This, in a way, is also a reprimand of Abram, as God's counteraction would eventually undo his own action and liberate Sarai from Pharaoh's harem. God's response circumscribes and rescinds commoditisation of human beings, particularly the objectification of women as sex objects for profit. This is a fitting corrective to the ethical quagmire of contemporary society that has no qualms at objectifying the sexuality of women (even family members, as in the anecdotes cited at the beginning of this essay) for material gain.

The anti-climax follows in Pharaoh's confrontation with Abram (Gn 12:18-19). Flowing from Yahweh's response to 
the male actions against Sarai, Pharaoh realises the scam to which he has fallen prey. He therefore takes the matter up with Abram, who remains speechless, a sign of his culpability. At the end, Pharaoh, uncharacteristic of the potentates of ANE, magnanimously sends Abram out of his territory with everything intact: his life, his wife and the loot of his scam. Abram's conduct shows how not to be the people of God. Pharaoh's actions highlight the needs to confront evil and yet not to seek vengeance when wronged.

Finally, in the denouement of the story (Gn 12:20-13:4), Abram finds his way back to the Negev en route Bethel, where he resumes his relationship with Yahweh again. Abram's misadventure in Egypt points to the truth of the words of the wise, 'Better is a little with righteousness than great revenues with injustice' (Prov 16:8 ESV; cf. Pr 17:1; Ps 37:17).

\section{Conclusion}

In this article, I set out to carry out an ethical narrative critical reading of Genesis 12:10-13:2. The passage was studied using the contemporary literary analytical (particularly the narrative critical) approach. In the course of the reading of the narrative, the interplay of the motifs of (sexual) desire, power play, peril, alterity and divine response to human overreaching and injustice became palpable. That folks in desperate situations act in despicable self-interested ways to the detriment of the other (particularly, the weak and powerless like women and immigrants, as in the anecdotes with which this essay began) is not limited to non-believers but even people of faith may be tempted to tread the same line. We began with a survey of interpretive history of the text; and situated it in its historical, compositional and literary contexts. The ensuing literary analysis of the text unveiled the dexterity of its author(s) and/or redactor(s), as its superb literary artistry conveyed its rhetorical import powerfully. Ultimately, theological and/or ethical lessons have been derived for contemporary people of faith, through paying careful attention to the plot and literary artistry of the narrative.

\section{Acknowledgements}

I am grateful to Langham Partnership, London, and Asbury theological Seminary, Wilmore, US, for providing the sponsorship for the research from which this paper was written. I am equally grateful to St. Joseph's University, Philadelphia, where this article was first presented as a public lecture. These opportunities and interactions helped shape my thought and paper, but I am solely responsible for its contents, and it does not reflect the positions of any of these Institutions.

\section{Competing interests}

The author declares that he has no financial or personal relationships which may have inappropriately influenced him in writing this article.

\section{References}

Alexander, T.D., 1992, 'Are the wife/sister incidents of genesis literary compositiona variants?', VT XLII(2), 145-153.

Arnold, B.T., 2009, Genesis, New Cambridge Bible Commentary, Cambridge University Press, Cambridge.

Bergant, D., 2013, Genesis: In the beginning, Liturgical Press, Collegeville, MN.

Brown, F., Driver, S.R. \& Briggs, C.A., 1907, The brown-driver-Briggs Hebrew and English Lexicon: With an appendix containing the Biblical Aramaic, Clarendon Press, Oxford.

Calvin, J., 1948, Commentaries on the first book of Moses, called genesis, vol. 1, transl. J. King, Eerdmans, Grand Rapids, MI.

Childs, B.S., 1968, 'Cave 11: Surprises and the question of canon', McCormick Quarterly 21, 284-298.

Childs, B.S., 1979, Introduction to the Old Testament as scripture, Fortress, Philadelphia, PA.

Finkelstein, I., 1995, 'The settlement of the philistines in Canaan', Tel Aviv 22(2), 213-239.' https://doi.org/10.1179/tav.1995.1995.2.213

Friedman, R.E., 1998, The hidden book in the book, Harper, San Francisco, CA.

Gunkel, H., 1997, Genesis, transl. M.E. Biddle, Mercer University Press, Macon, GA.

Holladay, W.L., 2000, A concise Hebrew and Aramaic Lexicon of the Old Testament, Based upon the Lexical Work of Ludwig Koehler and Walter Baumgartner, Brill, Boston, MA. (HALOT).

Hume, T., Cohen, L. \& Sorvino, M., 2013, 'The women who sell their daughters into sexual slavery', CNN, viewed 12 June 2016, from http://www.cnn.com/ interactive/2013/12/world/cambodiachildsextrade

Jeansonne, S.P., 1990, The women of genesis: From Sarah to Potiphar's wife, Fortress, Minneapolis, MN.

Joüon, P. \& Muraoka, T., 2006, A grammar of biblical Hebrew, Editrice, Pontificio Instituto Biblico, Roma.

Kautzsch, E. (ed.), 1910, Gesenius' Hebrew grammar, Second English Edition, Oxford University Press, New York. (Gesenius).

Keil, C.F. \& Delitzsch, F., 1949, Commentary on the Old Testament: The Pentateuch, vol. 1 , Eerdmans, Grand Rapids, MI.

Kertai, D., 2008-2009, 'The history of the middle-Assyrian empire', Talanta 40-41, 25-51.

Kuruvilla, C., 2014, 'Brazil's child prostitution problem', New York Daily News, June 18, viewed 06 December 2016, from http://www.nydailynews.com/news/world/ brazilchildprostitutionproblemarticle1.1835059

Long, V.P., 1993, 'First and second Samuel', in L. Ryken \& T. Longman (eds.), A complete literary guide to the bible, Zondervan, Grand Rapids, MI.

Muilenberg, J., 1969, 'Form Criticism and beyond', JBL 88, 1-18. https://doi. org/10.2307/3262829

Peleg, Y., 2006, 'Was the ancestress of Israel in danger?: Did Pharaoh touch (נגע) Sarai?', ZAW 118, 197-208. https://doi.org/10.1515/ZAW.2006.009

Pratt, R.L., Jr., 1983, 'Pictures, windows, and mirrors in Old Testament exegesis', WT 45, 156-167.

Pritchard, J.B. (ed.), 1969, Ancient near eastern texts relating to the Old Testament, 3rd edn., with supplement, Princeton University Press, Princeton, NJ. (ANET).

Rashkow, I.N., 1993, The Phallacy of genesis: A feminist-psychoanalytic approach, Westminster/John Knox, Louisville, KY.

Reis, P.T., 1992, 'Take my wife, please: On the utility of the wife/sister motif', Judaism 41(4), 306-315.

Sanders, J.A., 1976, 'Hermeneutics', in K. Crim (ed.), The interpreter's dictionary of the bible, supplementary volume, pp. 402-471, Abingdon, Nashville, TN.

Skinner, J.A., 1930, Critical and exegetical commentary on genesis, 2nd edn., T \& T Clark, Edinburgh.

Speiser, E.A., 1964, Genesis, Doubleday, Garden City, NY.

Steinberg, N., 1993, Kinship and marriage in genesis: A household economics perspective, Fortress, Minneapolis, MN.

Tigay, J.H., 2008, Issues in Jewish ethics: Adultery, Jewish Virtual Library, Encyclopaedia Judiaica, viewed 15 June 2016, from http://www.jewishvirtuallibrary.org/jsource/ Judaism/adultery.html

Trible, P., 1978, God and the rhetoric of sexuality, OBT, Fortress Press, Philadelphia, PA.

Tushima, C.T.A., 2011, The fate of Saul's progeny in the reign of David, Pickwick Publications, Eugene, OR.

Van Dijk-Hem, F., 1993, 'Sarai's exile: A gender-motivated reading of genesis 12:10-13:2', Pages 222-234 in A. Brenner (ed.), A feminist companion to genesis, Sheffield Academic Press, Sheffield.

Van Seters, J., 1975, Abraham in history and tradition, Yale University Press, New Haven, CT.

Von Rad, G., 1973, Genesis a commentary, 2nd edn., Westminster John Knox, Philadelphia, PA.

Wal, L.V., 2008, 'Responding to life's uncertainties - Deception (1): A meditation on genesis 12:10-20', CTJ 43, 79-82.

Walton, J.H., Matthews, V.H. \& Chavalas, M.W., 2000, The IVP bible background commentary: Old Testament, IVP, Downers Grove, IL.

Westermann, C., 1985, Genesis 12-36, transl. J.J. Scullion, S.J., Augsburg, Minneapolis, MN. 